\title{
The Dual Economy and Social Security in Rural China
}

\author{
Zheran Fan \\ School of Management, Wuhan University of Technology, Wuhan 430000, China \\ 522395628@qq.com
}

Keywords: Dual economy; Urban-rural gap; Rural China; Social security; Problem; Strategy

\begin{abstract}
China is now obviously in a dual economic era. The developed urban economy and the backward rural economy exist simultaneously while high-tech modern industry and ancient tradition of agriculture coexist at the same time. This dual economic model led to a huge gap between China's urban and rural social security in its project, level and coverage. Rural social security problems is salient. In order to solve this, approaches must be taken from the perspective of dual economic theory to analyse the institutional, strategic, practical and ideological reasons why urban social security system is superior to the rural one. With China's present reality taken into consideration, both long-term and short-term solutions will be given so as to advocate and strengthen the integration of urban and rural social security under the rule of law.
\end{abstract}

\section{Introduction}

Since the founding of the People's Republic of China, rural and urban areas have become two separate parts of the management, thus apparently forming a dual economic structure. This led to a huge difference between China's social security in the towns and rural areas, making the social security in rural areas far behind that of the towns and resulting in a series of social problems. The duality of economic structure is actually a common phenomenon which has aroused the world's well-known economists' s interests and gained their in-depth and systematic analysis. In 1954 American economist Arthur Lewis put forward a theoretical mode for developing country's dual economic structure. The model later after the supplement of Gustav Ranisi and Fei Jinghan formed Lewis-Ranis-Fei model. The formation, existence and strengthening of this dual economic structure have seriously affected the development of China's economy. In this case, farmers can neither share the fruits of social and economic development, nor get the social security or maintain their social security rights. China's dual economic structure extremely stands out together with its social problems. Therefore for the purpose to improve the rural social security and coordinate the developing goals of urban and rural social security according to the present China's Status quo, constructive measures should start from the solution to the abuses of dual economic structure.

\section{The Distinction in Social Security between Rural and Urban Areas in China}

Security Program. At present, the number of urban social security projects in China is large, with various kinds and wide range. The coverage is relatively comprehensive. However, in contrast to the comprehensive social security of urban society, there are still obvious institutional deficiencies, incomplete project and imbalanced project development and other issues in China's rural social security . [1] Most of the social security projects in rural areas are relatively simple and only related to the guarantee of basic living. They can only solve the problem of food and clothing for the majority of farmers, and therefore can not form a complete rural social security system and network. Due to the narrow coverage of rural social security at this stage, there is a big vacancy in the system. (See Table 1) 
Table 1 Contrast of social security items between rural and urban areas

\begin{tabular}{|c|c|c|c|}
\hline \multicolumn{2}{|c|}{ item } & Social security system in cities & Social security system in cities \\
\hline \multirow{5}{*}{$\begin{array}{l}\text { Social } \\
\text { insuranc } \\
\text { e }\end{array}$} & $\begin{array}{l}\text { Endowment } \\
\text { insurance }\end{array}$ & $\begin{array}{l}\text { Combined insurance of social pooling } \\
\text { and personal accounts }\end{array}$ & Family security-based \\
\hline & $\begin{array}{c}\text { Medical } \\
\text { insurance }\end{array}$ & $\begin{array}{l}\text { Combined insurance of social pooling } \\
\text { and personal accounts }\end{array}$ & $\begin{array}{l}\text { Rural cooperative medical } \\
\text { system }\end{array}$ \\
\hline & $\begin{array}{l}\text { Unemployme } \\
\text { nt insurance }\end{array}$ & $\begin{array}{c}\text { The insurance premium paid in } \\
\text { proportion to the total wages of the } \\
\text { employees }\end{array}$ & Barely built \\
\hline & $\begin{array}{l}\text { Employment } \\
\text { injury } \\
\text { insurance }\end{array}$ & $\begin{array}{l}\text { The insurance premium paid in } \\
\text { proportion to the total wages of the } \\
\text { employees }\end{array}$ & Barely built \\
\hline & $\begin{array}{l}\text { Maternity } \\
\text { insurance }\end{array}$ & $\begin{array}{c}\text { The insurance premium paid in } \\
\text { proportion to the total wages of the } \\
\text { employees }\end{array}$ & Barely built \\
\hline \multicolumn{2}{|c|}{ Social assistance } & $\begin{array}{l}\text { Urban subsistence allowances, special } \\
\text { relief, disaster relief ect. }\end{array}$ & $\begin{array}{l}\text { Rural subsistence allowances, } \\
\text { special relief, disaster relief ect. }\end{array}$ \\
\hline \multicolumn{2}{|c|}{ Social welfare } & $\begin{array}{l}\text { Urban community services, homes for } \\
\text { the elderly, welfare homes ect. }\end{array}$ & $\begin{array}{l}\text { Rural homes for the elderly, five } \\
\text { guarantees ect. }\end{array}$ \\
\hline
\end{tabular}

Support Level. In recent years, although the government has been increasingly put emphasis on rural social security and investing more funds, the gap in social security between urban and rural areas is still evident in terms of overall level. [2]Although the rural population accounts for more than half of China's total population, but can only enjoy less than a quarter of urban residents' social security funds treatment. Obviously, the social security level of rural residents is far less than that of the urban residents. First, the gap between urban and rural per capita social security expenditure is still large (Table 2). Second, the urban per capita social security expenditure is significantly higher than the rural areas. (Fig. 1 ) [3]

Table 2 Contrast of social security expenditure per capita between rural and urban areas(unit:RMB/per capita per year)

\begin{tabular}{|c|c|c|c|c|c|}
\hline Items $\quad$ Year & 2005 & 2006 & 2007 & 2008 & 2009 \\
\hline $\begin{array}{l}\text { Social security expenditure in cities } \\
\text { per capita of citizen }\end{array}$ & 1581 & 1793 & 2017 & 2426 & 2867 \\
\hline $\begin{array}{l}\text { Social security expenditure in } \\
\text { countryside per capita of citizen }\end{array}$ & 37 & 75 & 127 & 320 & 339 \\
\hline $\begin{array}{l}\text { Social security expenditure in cities } \\
\text { per capita of government }\end{array}$ & 620 & 681 & 807 & 835 & 960 \\
\hline $\begin{array}{l}\text { Social security expenditure } \\
\text { countryside per capita } \\
\text { government }\end{array}$ & 29 & 53 & 79 & 226 & 205 \\
\hline Items & 2010 & 2011 & 2012 & 2013 & 2014 \\
\hline $\begin{array}{l}\text { Social security expenditure in cities } \\
\text { per capita of citizen }\end{array}$ & 3292 & 3826 & 4486 & 5196 & 5876 \\
\hline $\begin{array}{l}\text { Social security expenditure in } \\
\text { countryside per capita of citizen }\end{array}$ & 520 & 860 & 127 & 1378 & 1521 \\
\hline $\begin{array}{l}\text { Social security expenditure in cities } \\
\text { per capita of government }\end{array}$ & 1050 & 1125 & 807 & 1378 & 1471 \\
\hline $\begin{array}{l}\text { Social security expenditure } \\
\text { countryside per capita } \\
\text { government }\end{array}$ & 313 & 508 & 79 & 702 & 800 \\
\hline
\end{tabular}


Source: China Statistical Yearbook(1999-2015), China Financial Yearbook(2008-2015), China Agricultural Statistical Yearbook(1999-2015)

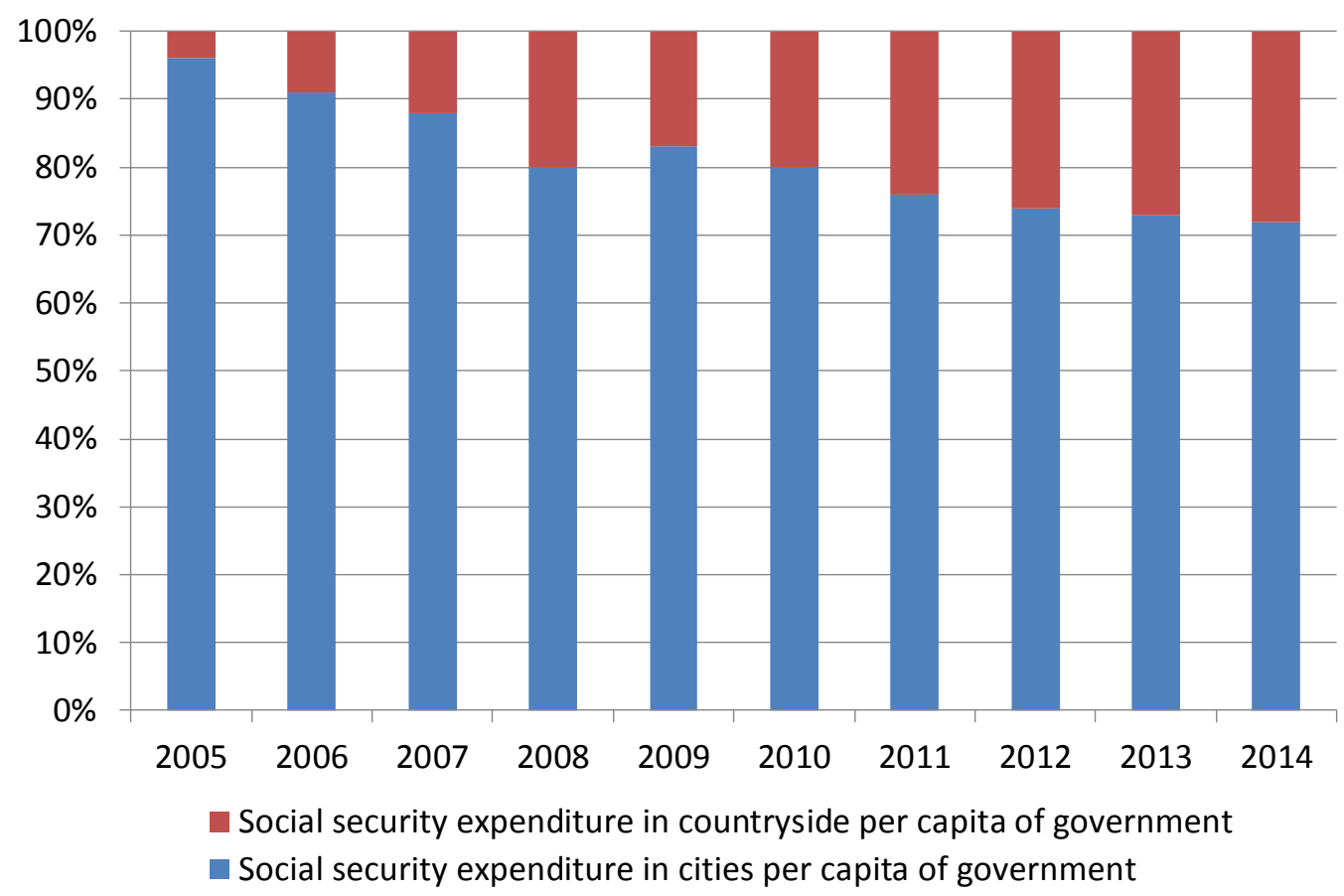

Figure 1. Finite Cities and countryside social security expenditure burden ratio

Social Security Coverage. On the present occasion, quality and type of social security in most of our rural areas are far from the town. [4] Taking medical insurance as an example: medical insurance in social security system of towns occupies an important proportion, but the results of rural medical insurance are not satisfactory. China's agricultural population accounts for $63.91 \%$ of the total population of the whole country. Out of 100 people in rural areas only 10 enjoy varying degrees of commercial or social coordinated medical insurance. While in large and medium-sized cities, this figure was 54. Since the formal implementation of the social security reform in 1999, there have been more than 100,000 people benefiting from it, of which nearly $65 \%$ are urban workers and retirees. [5] However the same rate for farmers is very low. As the largest coverage among various business and society insurance, the percentage of social co-ordination of serious medical insurance is less than 20. Moreover, $79 \%$ of rural farmers see doctors at their own expense, the guarantee rate is rather low. Therefore, it's not enough that the China's social security is only carried out in the cities. [6] It is vital for the economic construction in China that the social security coverage should be extended to the rural areas.

\section{Reasons for Low Social Security Standard in Rural Areas}

Institutional Reason: Dual Economic System. The dual economic system is the root cause of the backwardness of the rural social security system. The economic development in rural areas is far behind the level of the cities. At the same time the state expenditure towards rural social security is insufficient. In such a case, the rural collective economy and farmers will reduce the investment in social security, resulting in low social security standard of rural areas. [7]The dual economic structure itself caused the imbalanced resources distribution of urban and rural areas, gradually widened the gap between the two, and led to low income of farmers, therefore severely constrained insurance capacity.

Strategic Reason: "Efficiency First " Principle. Since the reform and opening up policy, China's policy of development strategy has always been efficiency first, then fairness. Based on the 
core value of efficiency, the socialist market economic system reform has boosted China's urban economy. In order to maintain the sustained and stable development of the urban economy, the state had to put limited funds into urban economic construction. [8]Finally, the government failed to put limited funds into the field of rural social security.

Practical Reason: Tremendous Pressure of Social Security in Town. The tremendous and urgent pressure of social security in town leave the government no time to take the rural areas into account. According to the statistics of Ministry of Labor and Social Security, until the end of June 2000, urban retired staff has reached 30.57 million while laid-off workers reached 11.2 million people.[9] In accordance with the principles of urban social security funds in China, the government needs to bear about $30 \%$ cost of social security of urban workers. Therefore, it is very difficult for the Government to provide social security expenditure for the above 40 million people. At the same time, because the urban workers have no land to cultivate, pension, medical care, unemployment insurance and other issues makes the situation more urgent than ever. The Government had no way but to solve the urban social security urgency first, casting most of the limited funds in the city and contributing little time and energy to take care of the countryside.

Ideological Reason: Unrealistic Thinking Mode of Rural Household Contract Responsibility System. After the implementation of rural household contract responsibility system, the thinking mode was set that the system could replace rural construction. Since then, the original part of the social security function shared by the rural collective disappeared due to the collapse of the collective economy and basically farmers' contracting right to the land, in fact, included major functions of rural residents social security. [10] This situation also allowed the government to ease the construction of rural social security. They believed that farmers had the contracting right to land, then all the rural security issues could be resolved, thus ignoring its construction.

\section{Measures to Establish Rural Social Security System}

From the national conditions of China, to include rural residents into the urban social security system and integrate the system to the national standard currently is clearly lack of realistic basis for social security in a long period of transition will still carry on a "two-track" operating mechanism in urban and rural areas. But since the initial distribution gap has been very unreasonable, further expanding the gap by the second distribution will not be allowed to happen. In the current and future years, the establishment of rural social security system should mainly take the following measures:

Improve the Minimum Living Guarantee Management in Rural Areas. It is essential to fully understand the importance of establishing the minimum living security system in rural areas, establish clear objectives and overall requirements of the rural minimum living security system, determine reasonable minimum living standard and target area of rural areas, standardize the minimum living guarantee management in rural areas, implement the minimum living guarantee funds in rural areas and strengthen the leadership to ensure the smooth implementation of the rural minimum living security system. As the rural economic development is uneven, income gap between developed and underdeveloped areas of rural residents is growing large. Such situation should be treated differently.

Set up a Standardized Social Security System of Urban and Rural Areas. According to the experience of China's development, we should further improve the integrated social security system of urban and rural areas, so that the social security management institutions in urban and rural areas can be standardized to make sure social security matters achieve unified decision-making and macro-control. To reduce management cost and to improve management efficiency and institutional equity, we must establish a nationwide social security network. But the unified social security system in urban and rural areas is not absolutely fair, yet is to allow a modest gap, to balance the interests of different groups and to handle treatment gap of social security in a reasonable range. Therefore the key is to look for a balance between fairness and efficiency and eliminate the urban rural gap brought by the dual economic system.[11] 
Build a High Level of Social Security Legislation. First, we should raise the level of social security legislation. The National People's Congress drives forward the local legislation, which elevates social security law from administrative laws and regulations to the highest legal form. In this way there are laws to go by for the implementation of rural social security system, which will make sure that urban and rural citizens' social security right is relatively uniform. Secondly, we will continue to improve the legal system of social security through legislation, formulating parallel legal documents such as Social Welfare Law, Social Assistance Law and Social Prosperity Law, and making appropriate changes and additions and deletions to the law according to the practical situation. Finally, the citizens' right to social security should be incorporated into and protected by of the Constitution in due course.

\section{Conclusion}

To solve the problem of rural social security faced by China is a key step in realizing and sharing the fruits of reform and development of the whole people. The fundamental measures are to eliminate the deformed dual economic model and to complete the transformation to "duality" to "unity", which is an important trail for China's economic development Model. If the issues can be tackled with the dual economic model so as to achieve the overall development of urban and rural social security, it will be a major leap in China's social security.

\section{Reference}

[1] Gu Dongbai: " Rural Social Security and Its Countermeasures Under the Dual Economic Structure in China" [J]. Journal of Luliang University of Education, Vol. 33(2016), No.4, p.28-30 (in Chinese)

[2] Gaofan et al: "On the Long - term Mechanism of Eliminating Dualistic Economic Structure in Urban and Rural Areas"[J]. Journal of Jianghai University, Vol. 11(2008), p.42-44 (in Chinese)

[3] Information on http://www.molss.gov.cn/gb/zwxx/ghytj.htm/2015-05-10/2015-05-17.

[4] Andrew Watson: "Social Security for China's Migrant Workers-Providing for Old Age"[J]. Journal of Current Chinese Affairs, Vol. 38(2009), No.4, p.42-44

[5] Shi Jing: "Study on Rural Social Security System in China"[J]. Journal of Hebei North University, Vol. 31(2015), No.6, p.65-68 (in Chinese)

[6] Jane Duckett: "China's social security reforms and the comparative politics of market transition"'[J]. Journal of Communist Studies and Transition Politics, Vol. 19(2003), No.1,p.22-28

[7] Joe C.B: "Leung. Social security reforms in China: issues and prospects"[J]. International Journal of Social Welfare, Vol. 12(2003), No.2,p.17-19

[8] Juan CHEN, Shaolei YANG: "Rural Social Security System of China: Problems and Solutions"[J]. Studies in Sociology of Science, Vol. 15(2014), No.1,p.8-15

[9] Huang Qingfeng, Liu Yige: "Changes of Evolutionary Logic and Path Selection of Rural Social Security System”[J]. Social Security Studies, Vol. 2(2014), p.38-45 (in Chinese)

[10] Tianhong Chen,John A: "Turner. Fragmentation in Social Security Old-Age Benefit Provision in China"[J]. Journal of Aging \& Social Policy, Vol. 27(2015), No.2, p.2-5

[11]Xi Zhou.: "The Reasons of Integrity Deficiency of Social Insurance in China [J]. Journal of Service Science and Management, Vol. 10(2017), No.2,p.7-14 